\title{
SPECIES-SPECIFIC DAPHNIA PHENOTYPES: A HISTORY OF INDUSTRIAL POLLUTION AND PELAGIC ECOSYSTEM RESPONSE
}

\author{
Nelson G. Hairston, Jr., ${ }^{1,3}$ Colleen M. Kearns, ${ }^{1}$ Linda Perry Demma, ${ }^{1,4}$ And Steven W. Effler ${ }^{2}$ \\ ${ }^{1}$ Department of Ecology and Evolutionary Biology, Cornell University, Ithaca, New York 14853-2701 USA \\ ${ }^{2}$ Upstate Freshwater Institute, P.O. Box 506, Syracuse, New York 13214 USA
}

\begin{abstract}
Phenotypic differences among species, even closely related species, may translate into distinct effects on ecosystem dynamics. In lakes, the generalist grazer genus Daphnia often has marked effects on the abundance of primary producers, the rate of primary production, and rates of nutrient cycling. The effects are particularly distinct during the clear-water phase (CWP) when algal biomass is driven to extremely low values as Daphnia densities undergo an annual population increase. Here we show that the timing of the CWP in Onondaga Lake, New York, USA, has depended upon which Daphnia species were present in the water column. An analysis of the ephippia and diapausing eggs from the sediments reveals that long-term changes in the zooplankton species assemblage tracks a history of chemical (especially salt waste) pollution. Prior to 1930 the assemblage was dominated by native $D$. pulicaria and D. ambigua. From 1930 to 1980 , these species were replaced by $D$. exilis and $D$. curvirostris, two salinity-tolerant exotic species native to shallow salt pools of the southwestern United States and coastal brackish ponds of Europe, respectively. As industry was progressively shut down by government action over the period from the 1970 s to the 1980 s, the exotic species disappeared, and the two native taxa returned (plus $D$. galeata mendotae, which is also native to the region). As we have shown previously, the exotic species were identified either by hatching and rearing diapausing eggs $(D$. exilis $)$ or by analysis of eggs using mtDNA (D. curvirostris). We interpret their role in seasonal algal dynamics in Onondaga Lake retrospectively using data collected in prior studies of the lake. The native Daphnia currently cause a typical spring CWP in late May and early June, whereas the exotic species caused an unusual late-summer (August-October) CWP during the period of maximum cyanobacterial density.
\end{abstract}

Key words: algae; clear-water phase; consumption; diapausing eggs; mtDNA; Onondaga Lake; paleolimnology; zooplankton.

\section{INTRODUCTION}

Paleoecological studies provide a powerful avenue for understanding the effects of environmental change on species composition and the impacts of these changes on ecological and ecosystem processes. Margaret Davis' studies of the effects of climate change on tree species assemblages are excellent examples (e.g., Davis 1987 , Davis et al. 1994) that provide critical background for understanding the impact of environmental change on community dynamics (Davis et al. 1998) and biogeochemical cycling (Lovette and Rueth 1999). By counter-example, these studies illustrate the potential danger in pooling species into large categories (e.g., trophic levels, guilds, successional stages) to facilitate the consideration of broad ecological patterns and dynamics (e.g., Root 1967, Cyr and Pace 1993, Hairston and Hairston 1993). Doing this loses information about

Manuscript received 24 November 2003; accepted 16 June 2004; final version received 19 August 2004. Corresponding Editor (ad hoc): L. J. Graumlich. For reprints of this Special Feature, see footnote 1, p. 1667.

${ }^{3}$ E-mail: ngh1@ @ornell.edu

${ }^{4}$ Present address: Emory University Vaccine Research Center, 954 Gatewood Drive, Atlanta, Georgia 30329 USA. phenotypic differences both among species and among genotypes within a species that may translate into distinct ecosystem dynamics (e.g., Hairston and Hairston 1993, Sterner and Elser 2002).

Individual species of consumers can have distinct effects on the dynamics of primary producers. Some terrestrial herbivores are specialists while others are generalists, some insect populations have a tendency to "outbreak" and others do not, and many can have substantial effects on rates and routes of nutrient cycling (e.g., McNaughton et al. 1997, Price 1997, Post et al. 1998). In pelagic habitats, planktonic crustaceans that graze phytoplankton frequently differ substantially among species in their impacts on nutrient mineralization (Lehman 1984, Sterner and Elser 2002), algal assemblages (Schaffner et al. 1994, De Mott 1995), and primary production (Elser et al. 1988, Lampert and Sommer 1997). This contrast is particularly striking for copepods and cladocerans, two of the most abundant primary consumers in many lake ecosystems.

One highly visible effect of zooplankton on primary producers is the clear-water phase (CWP), in which the spring phytoplankton bloom terminates with a period of marked reduction in algal biomass and increased 
water transparency. Clearing coincides with a substantial increase in the abundance of Daphnia (Lampert and Sommer 1997) and a corresponding rise in the concentration of biologically available phosphorus (Lampert et al. 1986). The spring Daphnia increase is caused by a combination of hatching by diapausing eggs from lake sediments and enhanced population growth during warming spring conditions (Hülsmann and Voigt 2002); grazing by these Daphnia and other consumers is largely responsible for the spring clear water (Lampert et al. 1986, Dawidowicz et al. 2002). Other factors may also be involved in the timing and production of the CWP (Kalff 2002), but grazing unquestionably plays the dominant role.

Whereas the impact of Daphnia on algal biomass is widely recognized, the functional role of this taxon as a grazer in pelagic ecosystems has usually been described as one typical of large cladocerans in general (e.g., Mazumder 1994, Cottingham et al. 1997). Occasionally, distinctions have been made between largebodied and small-bodied species, particularly in relation to grazing rate (Knoechel and Holtby 1986, Mazumder 1994), nutrient mineralization (Sterner and Elser 2002), and phytoplankton species composition (Tessier et al. 2001). Daphnia species differ phenotypically in ways other than body size. In particular, they can have distinct seasonal phenologies that can result in different, species-specific impacts on the temporal dynamics of primary producers. For these reasons, variation in the effects that grazing Daphnia species have on algal biomass either among lakes, or between years for a single lake, could be in part explained by variation in the particular species of Daphnia present.

In the paleolimnological case study we present here, the Daphnia species assemblage in Onondaga Lake, New York, changed over the past century as a result of changing industrial and municipal pollution. This history provides an opportunity to explore the relationship between grazer phenotypes and the dynamics of the primary producers they consume. Using diapausing eggs recovered in sediment cores, we reconstruct a history of plankton dynamics in Onondaga Lake. Diapausing eggs have extraordinary potential in paleolimnological studies. Where they can be hatched, it is possible to trace long-term temporal changes in both genetic composition (Weider et al. 1997, Hairston et al. 1999) and physiological phenotype (Cousyn et al. 2001, Hairston et al. 2001) of a population. Where they cannot be hatched, it is often possible to extract DNA for use in inferring ecological and evolutionary dynamics (Gomez et al. 2000, Duffy et al. 2000).

For Onondaga Lake Daphnia, we show how the timing of the CWP of Onondaga Lake has depended critically upon shifts in Daphnia species from native to pollutant-tolerant exotics and back again to natives, apparently depending upon industrial activity in the watershed. This means that different species of grazers within the same genus have had distinct effects on the seasonal dynamics of primary producers.

\section{A brief history of the pollution of Onondaga Lake}

Onondaga Lake (see Plate 1) lies at the northern edge of Syracuse, New York, where industrial development and human-population increase began in the 1800 s and continued through most of the 1900s. We are primarily concerned here with industrial saline wastes, and to a lesser extent nutrient-enriched sewage effluent. However, other pollutants have also entered the lake, especially mercury, and in 1994 the sediments of Onondaga Lake were added to the superfund National Priority List (Effler 1996). Onondaga Lake is naturally slightly saline as brines drain into the basin from Upper Silurian-aged salt deposits (Effler 1996). A salt-production industry starting in 1787 , followed by soda ash $\left(\mathrm{Na}_{2} \mathrm{CO}_{3}\right)$ production starting in 1884 , led to industrial pollution with peak ionic waste loading to the lake of $2500 \mathrm{Mg} / \mathrm{d}$ (Effler 1996). Though no direct measurements of water-column salinity were made prior to the late 1960s, Rowell's (1996) paleolimnological study showed a rise in the abundance of salt-tolerant diatom species beginning at about 1900, followed in the 1930 s by a marked increase in the percentage of halophilic species and a decline in those that are halophobic.

Direct salinity measurements began in 1968 (Effler et al. 1996) when water-column values exceeded $3 \mathrm{~g} /$ $\mathrm{L}$ (about $5.5 \mathrm{mS} / \mathrm{cm}$ ). This is a commonly accepted boundary between "fresh" and "saline" lake waters (Kalff 2002), where osmotic stress to many freshwater zooplankton is significant (Remane 1971). Salinity remained at or above $3 \mathrm{~g} / \mathrm{L}$ until 1986, when industrial soda ash production ceased. Within two years, salinity had dropped to less than $1.5 \mathrm{~g} / \mathrm{L}$, and by 1990 it was near its current value of about $1 \mathrm{~g} / \mathrm{L}$.

In addition to industrial pollutants, increasing municipal sewage input between 1900 and 1970 caused water-column total inorganic phosphorus to reach values as high as $2000 \mu \mathrm{g} / \mathrm{L}$ in the late 1960s. Despite decreased P loading to the lake beginning in the early 1970s, summer average values continue to exceed 50 $\mu \mathrm{g} / \mathrm{L}$ in most years (Effler 1996, Matthews et al. 2001). In the late 1960s, summer primary producers were comprised largely of cyanobacteria (Sze and Kingsbury 1972), and water-column chlorophyll-a values likely exceeded $200 \mu \mathrm{g} / \mathrm{L}$ (Effler 1996). Mean summer chlorophyll $a$ concentrations during the 1980 s varied between 35 and $75 \mu \mathrm{g} / \mathrm{L}$ (maximum values $>120 \mu \mathrm{g} / \mathrm{L}$ ) and declined through the 1990s to $20 \mu \mathrm{g} / \mathrm{L}$ (Effler 1996, S. W. Effler, unpublished data).

Auer et al. (1990) noted that, during 1979-1986, summer-time water transparency was poor when Daphnia and other larger planktonic crustaceans were rare or absent. Mean Secchi disk depth averaged less than one meter with little variation during the ice-free season (Fig. 1, open circles show years included in Auer 


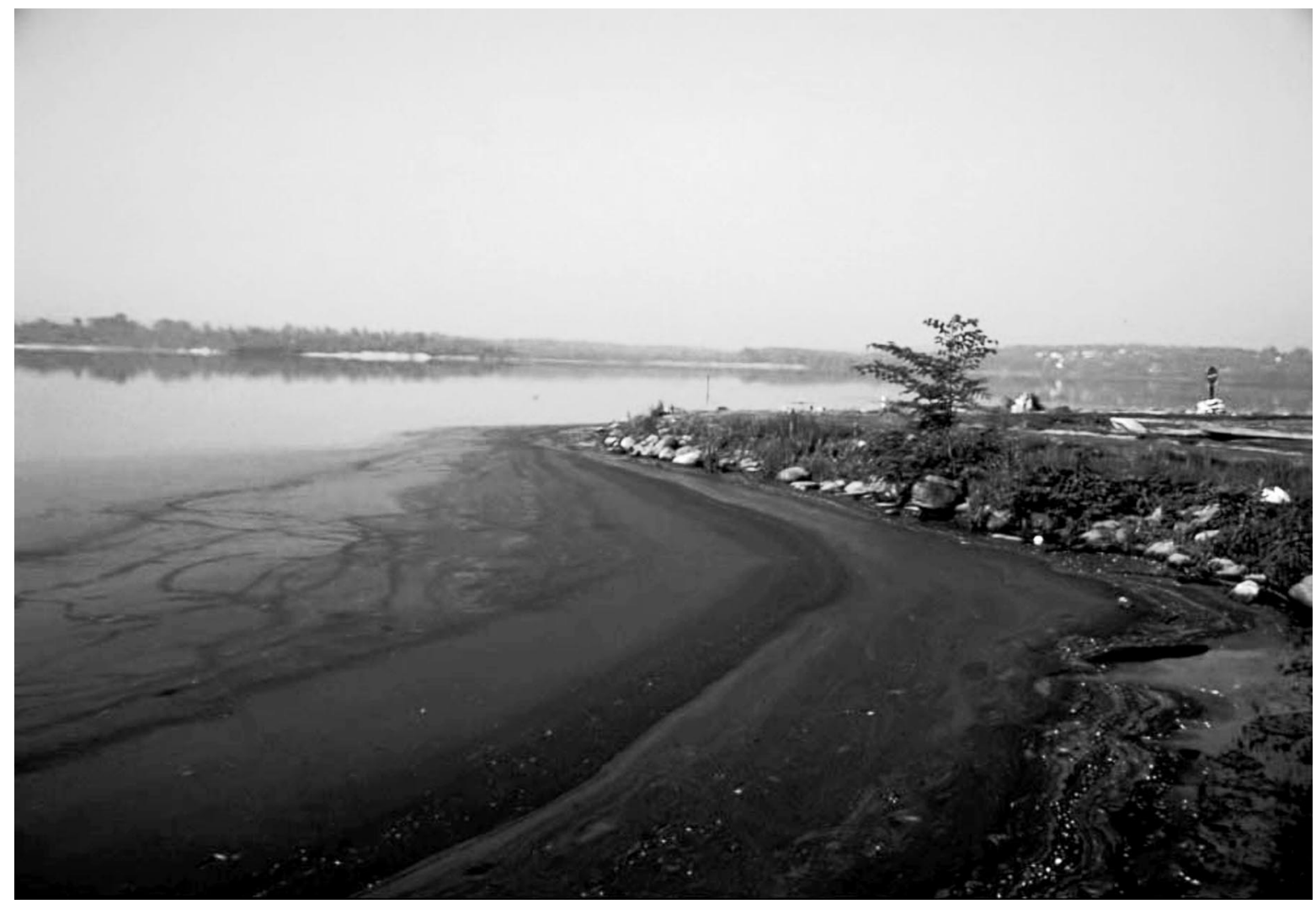

Plate 1. Rafts of ephippia (egg cases containing diapausing eggs) of Daphnia galeata mendotae trapped in the surface film of Onondaga Lake, New York, at the end of the clear-water phase in spring 1998. Each of the bands of material visible along the shore is composed of ephippia of differing concentrations. Tracks left by ducks swimming through the ephippia can be seen in the band farthest from shore, which is interesting because ducks are often hypothesized to be vectors transporting zooplankton diapausing eggs among lakes. Photo credit: Bruce A. Wagner.

et al. 1990). The year following the closing of the soda ash industry in 1986, three genera of relatively large crustaceans, Daphnia, Diaphanosoma, and Diaptomus, appeared in the plankton and remained seasonally present through 1989, the end of the Auer et al. (1990) study. For 1987-1989, mean water transparency increased substantially, as did the variation among dates. Auer et al. (1990) showed that this change is a product of elevated grazing in early summer causing a crash in phytoplankton and increase in water clarity that is the clear-water phase. The question we address here is whether the exotic Daphnia also caused a CWP and if so, how its timing and extent compared with that produced by the native species.

\section{Methods}

\section{Study site and sediment coring}

We took sediment cores at $17 \mathrm{~m}$ depth at a "saddle" lying between two $18 \mathrm{~m}$ deep and $19 \mathrm{~m}$ deep basins of Onondaga Lake (12 $\mathrm{km}^{2}$ surface area). Based upon comparisons of sediment horizons for mercury and carbonate between our cores and those taken in the two basins (Rowell 1996), it appears that the existence of the saddle may be entirely due to elevated deposition rates of sediment entering the lake from primary industrial waste beds directly adjacent to this area of the lake.

Piston cores, taken by scuba diver, were processed according to methods in Hairston et al. (1999) and Duffy et al. (2000). ${ }^{210} \mathrm{~Pb}$-dating for the core reported here is reasonably secure at sediment ages more recent than 1970 , but is less reliable for earlier dates when sediment accumulation rates were variable (consistent with variation in industrial activity and disposal practices for this waste; Effler 1996) and when the supported ${ }^{210} \mathrm{~Pb}$ activity of parent material changed (see Hairston et al. 1999). However, the ${ }^{210} \mathrm{~Pb}$-dating for the critical sediment horizons of increases in mercury pollution during the 1930s (O’Brien and Gere Engineers 1990) and $\mathrm{CaCO}_{3}$ between 1900 and 1940 (PTI Environmental Services 1992) appear to be consistent with the history of industrial pollution.

We inferred the abundance of different Daphnia species through time by analyzing the density of ephippia (i.e., chitinous cases containing diapausing eggs) and the density of identifiable eggs within ephippia in each 


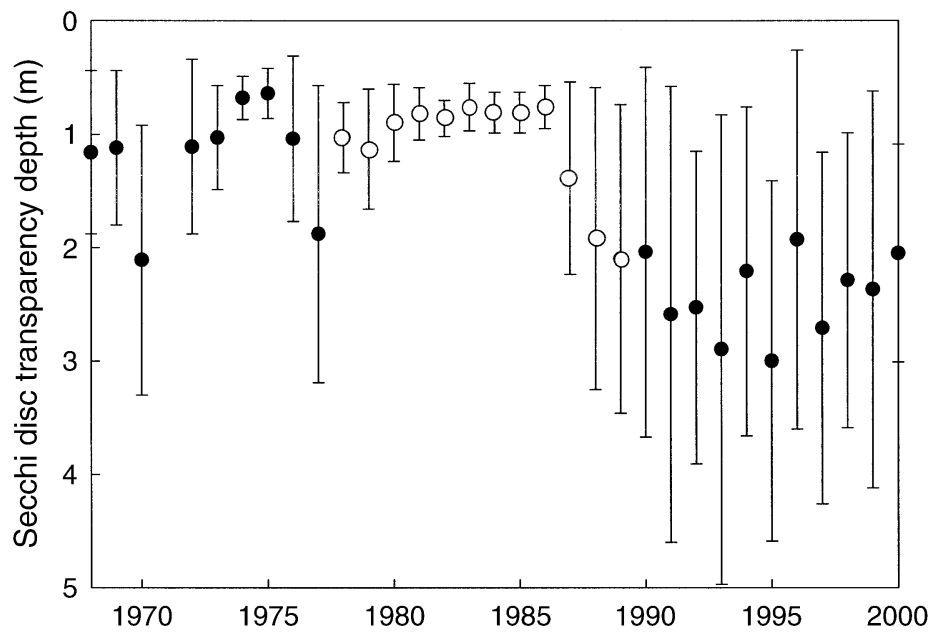

FIG. 1. Means \pm SD of Secchi disk transparencies in Onondaga Lake, New York, USA for the years 1968-2000 (1971 is excluded because data exist for only a single date). Means and standard deviations were greater in years when Daphnia were abundant (1968-1977 for exotic species and 1987-2000 for native species) than when Daphnia were scarce or absent (1978-1986). Open circles are used to highlight the years previously discussed by Auer et al. (1990).

sediment slice. Because the densities of eggs and ephippia show similar occurrence patterns, we only report egg densities here. For species that are native to other lakes in the region of Onondaga Lake, we were able to make taxonomic identifications based upon ephippial morphology (shape and spinulation). We confirmed these identifications by hatching samples of eggs from ephippia of different morphological types and rearing them for identification based on adult morphology. For the ephippia of exotic species, morphological identification was either uncertain or impossible. In these cases, we either hatched eggs, reared the animals and assessed adult morphology and allozyme patterns (Hairston et al. 1999), or identified the species using genetic sequences obtained from mitochondrial DNA extracted directly from the eggs (Duffy et al. 2000).

\section{Zooplankton sampling and water transparency}

During 1996, we sampled zooplankton and measured Secchi disk transparency at the "saddle" station on 25 dates between 3 April and 15 November, and in 1997 on 21 dates between 2 May and 29 October. We collected duplicate zooplankton samples using a ClarkeBumpus sampler fitted with a $75-\mu \mathrm{m}$ mesh net towed diagonally between $1 \mathrm{~m}$ above the bottom and the lake surface. Samples were preserved in $70 \%$ ethanol, and in the laboratory, subsamples were counted in a Borgorov-Litt tray under a dissecting microscope at $40 \times$.

\section{RESULTS}

\section{Daphnia species replacement in Onondaga Lake}

Diapausing-egg densities show a pattern of Daphnia species replacement through time (Fig. 2). Early in the 1900 s, the Daphnia assemblage was made up exclusively of two species native to the northeastern United States: D. ambigua and D. pulicaria. The former species disappeared before 1910 and the latter by the mid1930s. Hairston et al. (1999) found that, at about the time $D$. pulicaria disappeared, the exotic species $D$. exilis first invaded Onondaga Lake. This species occurs naturally in temporary, fishless, saline pools in the southwestern United States and northern Mexico (Hebert and Finston 1993) and had not been reported previously east of the Mississippi River (Hebert 1995). The species became established in the 1930s, peaked in abundance around 1970, and persisted in sediments dated at about 1980 (though historical plankton data suggest it was absent by 1978; Meyer and Effler [1980]). Duffy et al. (2000) showed that a second exotic species, D. curvirostris, invaded the lake about 1960 , attained modest numbers and disappeared by 1980 . This species is native to Europe and Asia and has only once been reported from North America, in Northwest Territories, Canada (Hebert 1995). Its ecological distribution has not been well studied, but it is known to occur in brackish coastal ponds and temporary wetlands in western Europe (Ortega-Mayagoitia et al. 2000, Michels et al. 2003; and material from F. Bastiansen and K. Schwenk, unpublished data) and in naturally saline ponds and heavy-metal-polluted minewaste pools in central Europe (A. Petrusek, personal communication).

We do not have any direct evidence to explain how these exotic species arrived at Onondaga Lake, but circumstantial evidence suggests that they were transported as ephippial eggs in mud adhering to industrial equipment. Cladoceran diapausing eggs can survive the kind of desiccation and transport that would have been required (e.g., Fryer 1996). Roland Hazard, who started the soda ash industry on the shores of Onondaga Lake in 1884, also owned a lead mine in Missouri (Cominolli 1990), the eastern-most extent of the natural range of D. exilis (Hebert and Finston 1993). Ephippia could easily have been carried by personnel traveling between Missouri and Syracuse, New York. In addition, Hazard's company was co-owned by two Belgians, Ernest and Alfred Solvay. Engineers made numerous trips during the early 1900s between factories in Europe and on Onondaga Lake (Cominolli 1990), affording opportunities for the inadvertent transport of ephippia. 


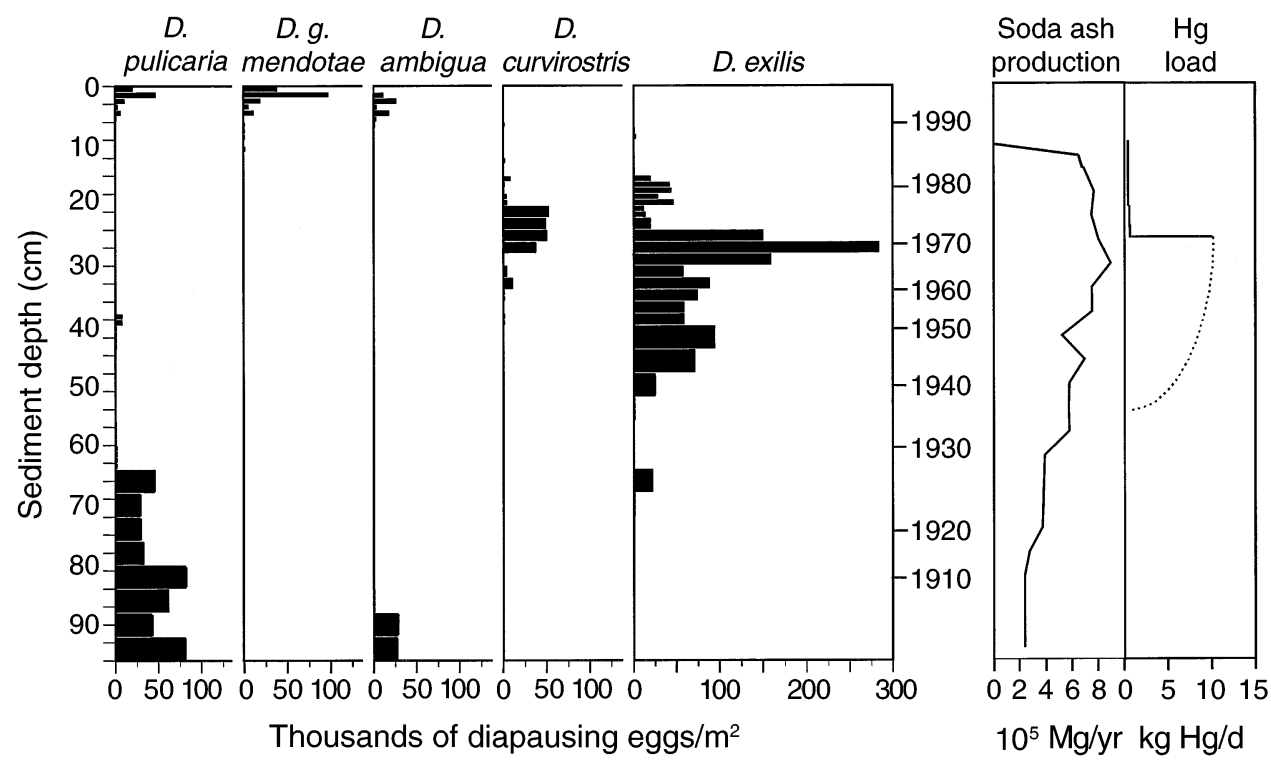

FIG. 2. Distribution of the diapausing eggs of five species of Daphnia in the sediments of Onondaga Lake, New York, illustrated together with two components of the history of lake pollution. D. pulicaria, D. g. mendotae, and D. ambigua are species native to central New York State (i.e., the Onondaga Lake region), whereas D. curvirostris and D. exilis are exotic species that became established during the period of peak industrial pollution. Ionic waste loading is illustrated using the record of annual industrial soda ash production, and mercury $(\mathrm{Hg})$ pollution is illustrated using known time points for changes in industrial loading rates. The dotted line for mercury loading indicates that we do not know the shape of the curve connecting these points, but we are close, based on sediment $\mathrm{Hg}$ analyses (C. Driscoll, unpublished data). Dates are determined by ${ }^{210} \mathrm{~Pb}-$ dating (see Methods).

It is unclear why the exotic Daphnia disappeared from Onondaga Lake around 1978, before the industry was forced to close in 1986 and lake salinity declined. Perhaps the reduction in mercury pollution (Fig. 2) during the 1970s (Effler 1996) led to an increase in fish spawning success and hence elevated predation on the large-bodied exotic daphniids. Alewife (Alosa pseudoharengus), an obligate size-selective planktivore (Brooks and Dodson 1965), was not found in a fish survey in the late 1960s (Onondaga County 1971), but was reported to be common in 1978 (Meyer and Effler 1980). In addition, chemical stress that began in 1980 due to elevated ammonia in the municipal effluent (Effler 1996) had an unknown effect on Daphnia.

The native daphniid species were absent throughout the period the exotics were present, except for a brief occurrence of D. pulicaria dated around 1950 (a year when the production of soda ash, and its accompanying ionic pollution was halted by a labor strike, Effler 1996). After the exotic species disappeared, both previously present native species reinvaded in the late 1980s along with Daphnia galeata mendotae (also called Daphnia mendotae; Hebert [1995]), a species native to the northeastern United States. The timing of recolonization (1987, according to plankton samples; Auer et al. [1990]) corresponds precisely with the marked decline in lake salinity that accompanied the cessation of soda ash production in 1986 (Effler 1996). The abundance of diapausing eggs of the native species generally increases in the top $3 \mathrm{~cm}$ of the core (Fig. 2).

\section{Zooplankton abundance and water transparency}

The planktonic Daphnia species assemblage in 1996-1997 was dominated by D. g. mendotae. D. pulicaria was present in low numbers only from 9 July to 27 August 1996 and 15 July to 20 August 1997; D. ambigua was only found in samples from one date: 18 September 1997. Taken together, the Daphnia species show a typical spring increase and abundance peak in both years (Fig. 3, top). During the seasonal peak in grazer density, water-column transparency increased markedly (i.e., a typical CWP in 1996-1997; Fig. 3, bottom), with Secchi depths increasing from 1 to $2 \mathrm{~m}$ in early spring to greater than $6 \mathrm{~m}$ at the end of May and early June, and then declining again to $<2 \mathrm{~m}$ by July.

\section{DISCUSSION}

\section{Species extinction and replacement, and ecosystem dynamics}

The Daphnia species assemblage in Onondaga Lake shifted from species typical of freshwater lakes in central New York State in the early 1900s to salinity-tolerant exotic species during the period of ionic-waste pollution, and then back again to native taxa after the polluting industry closed in 1986 (Fig. 2). Consistent 

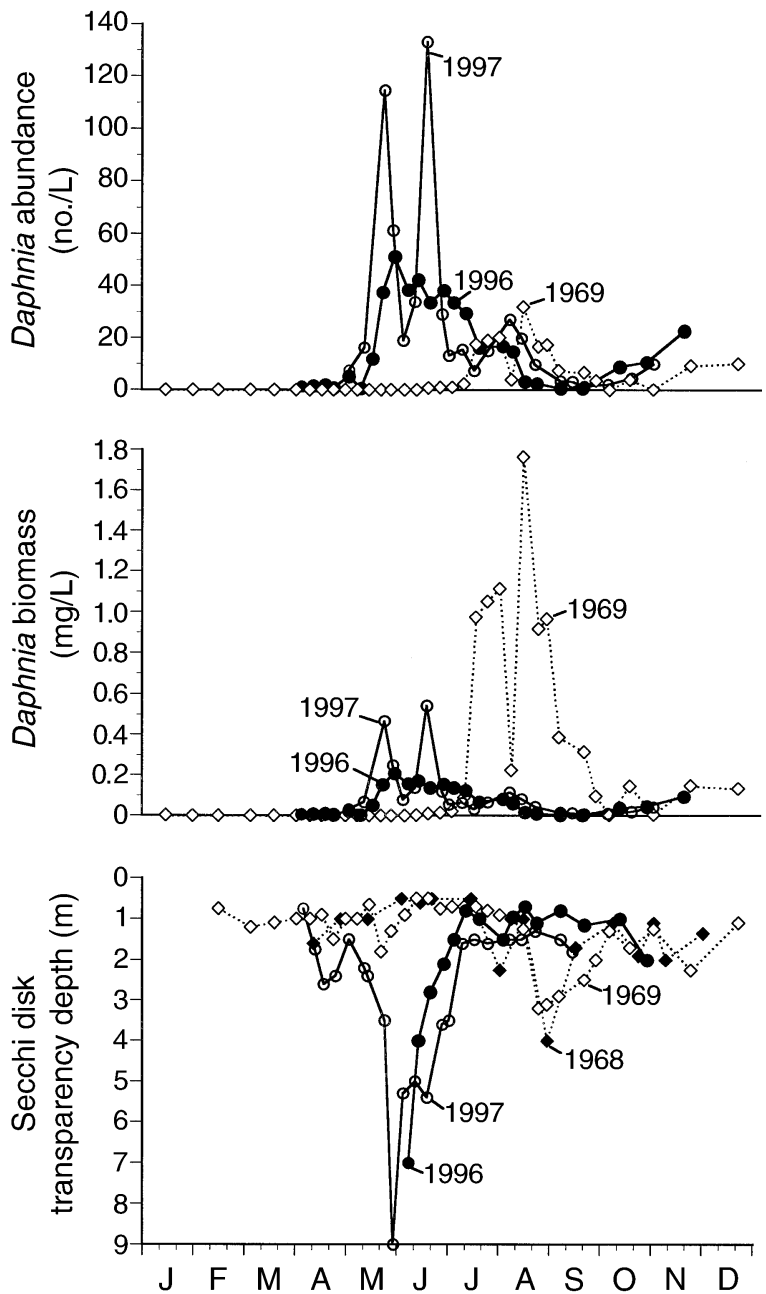

FIG. 3. The seasonal abundance (top) and biomass (middle) of Daphnia species in Onondaga Lake, New York, and the timing of the CWP (clear-water phase) as illustrated by Secchi disk transparency (bottom). During 1968-1969, when two exotic species, D. exilis and D. curvirostris, were present, Daphnia density and biomass peaked and water transparency was greatest in late summer. During 1996-1997, when three native species, $D$. pulicaria, $D$. g. mendotae, and $D$. ambigua were present, Daphnia density and biomass peaked and water transparency was greatest in late spring. The biomass data give a different picture of relative densities than the abundance data, because $D$. exilis is substantially larger in body size than any of the other species.

with previous research (Auer et al. 1990), we observed a distinct water clearing event in 1996 and 1997. We wish to know, however, if the exotic species, abundant in the lake prior to 1978 , also produce a CWP, and if so, when?

Data on Onondaga Lake zooplankton during the period that exotic species dominated are available only for 1969 (Onondaga County 1971). The Daphnia species reported, D. similis and D. pulex, have been reidentified as $D$. exilis (Hairston et al. 1999) and $D$. curvirostris (Duffy et al. 2000), but the seasonal phe- nologies are instructive. The peak abundance of the two exotic Daphnia species in 1969 did not occur during the spring as was the case with the native taxa during the 1990s, but rather later in summer between late July and early September (Fig. 3, top). Consistent with the late-summer occurrence of Daphnia, the CWP in 1968 and 1969 (Onondaga County 1971) was delayed by nearly four months relative to the spring clearing observed in 1996 and 1997.

Although relatively low in abundance, the exotic Daphnia (Fig. 3, top) nevertheless appear to have been able to produce a clearing event (Fig. 3, bottom), presumably because $D$. exilis is substantially larger in body size than the native taxa ( $D$. curvirostris is approximately the same size as $D$. pulicaria), and hence had a disproportionate grazing impact. It is in fact impressive that even these large Daphnia could produce a distinct CWP during a period when total phosphorus was $\geq 2000 \mu \mathrm{g} / \mathrm{L}$, chlorophyll a was $\geq 200 \mu \mathrm{g} / \mathrm{L}$, and the phytoplankton was dominated by cyanobacteria. Estimates of biomass densities, based on length-weight regressions for Daphnia (Bottrell et al. 1976), were much greater when the exotics were present than in the years when the natives dominated (Fig. 3, middle). Because grazing rate is strongly related to body size in Daphnia species generally (Knoechel and Holtby 1986, Lampert 1987), this means that potential grazing pressure was more intense when the exotic species were present. Although it would be very interesting to know the seasonal dynamics of $D$. exilis and $D$. curvirostris in their native habitats and whether or not they produce a late summer CWP, there is unfortunately very little published information that addresses these questions. A single study of a population in a much warmer climate than Onondaga Lake, a seasonal wetland in southern Spain (Ortega-Mayagoita et al. 2000), found that D. curvirostris occurred only in spring.

While the study by Auer et al. (1990) of the Onondaga Lake CWP ended with data from 1989, our more recent data show that the seasonal clearing event continued through 2000 (Fig. 1). Prior to 1978, when the exotic Daphnia were present, the mean and variance of Secchi disk depth show that CWP dynamics were likely present throughout most of 1968-1977 (Fig. 1; filled circles). The variation in the extent of its development (as measured by standard deviation of Secchi transparency, Fig. 1) may have its origin in the fact that the exotic species were on their way out between 1968 and 1977 (Fig. 2). Alternatively, it may be that the exotic Daphnia, when abundant, were unable to exert consistent control, perhaps because algal edibility varied among years.

Plotting all Secchi disk measurements available for each time period shows a consistent pattern. When exotic D. exilis and D. curvirostris were present (19681977), the CWP occurred in late summer, primarily August-October, though some clearing events occurred as early as July (Fig. 4, top). In contrast, when native 


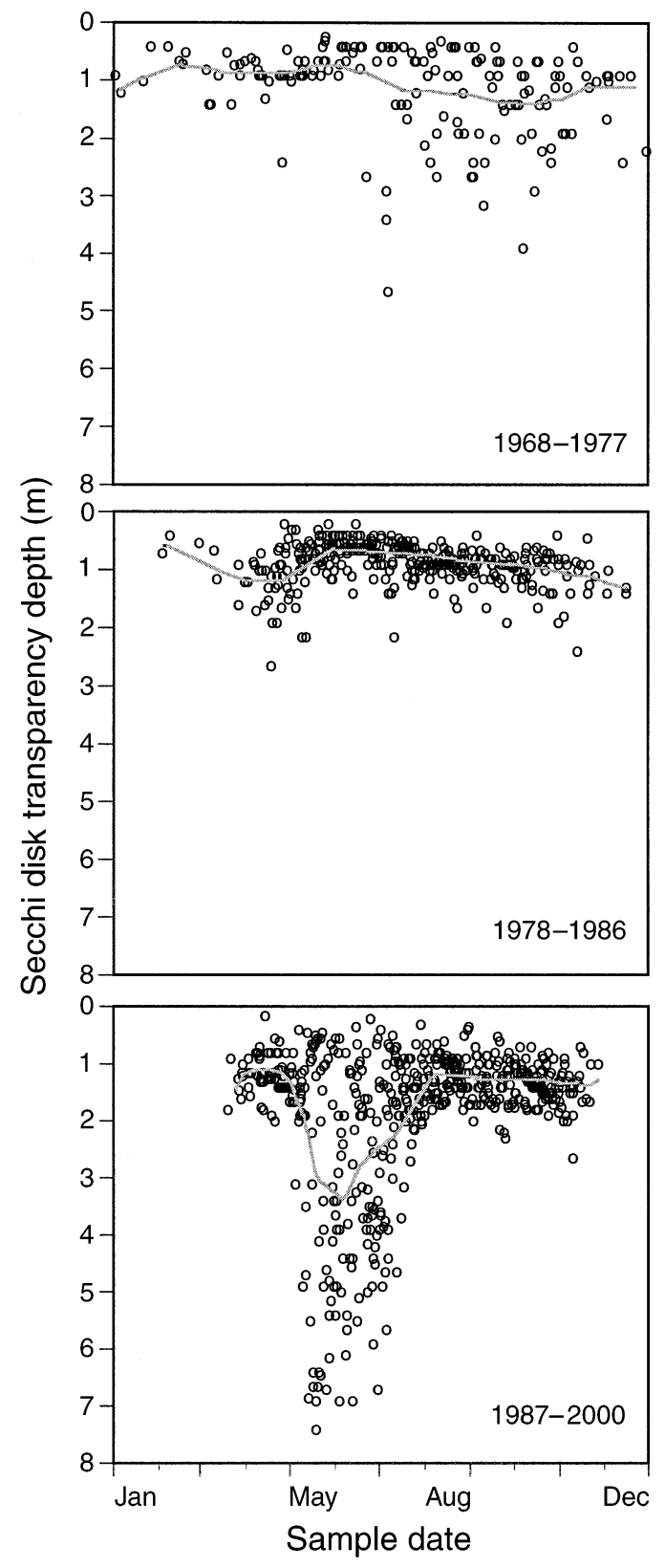

FIG. 4. Secchi disk transparency data for three time periods in Onondaga Lake, New York. During 1968-1977, when exotic Daphnia were present, maximum water transparency occurred late in the summer. During 1978-1986, when Daphnia were effectively absent from the water column, transparency was consistently low throughout the year. During 1987-2000, when native Daphnia were present, maximum water transparency occurred in late spring, on average four months earlier than when the exotics dominated. The smooth curves in each panel are nonparametric estimates of mean Secchi depth as a function of day of the year, using kernel regression (Bowman and Azzalini 1997), with smoothing bandwidth chosen by cross-validation (functions hev and sm.regression from the sm package in version 1.5.0 of R; $\mathrm{R}$ Development Core Team 2004).
D. ambigua, D. pulicaria, and D. g. mendotae were present (1987-2000), the CWP took place primarily in June, though it sometimes began in late May or ended in July (Fig. 4, bottom). When Daphnia were effectively absent (1978-1986), there was no CWP in any year (Fig. 4, middle). The mean date (5 September) of maximum Secchi transparency during the years that the exotic Daphnia were present is three months later than the mean date ( 3 June) when the native species dominated (difference significant, $t=6.42$, df $=7, P<$ 0.0002).

We have difficulty envisioning any viable alternative to variation in Daphnia grazing impact to explain the long-term changes in the expression of the CWP in Onondaga Lake. Because variation in chemical pollution caused the species and abundance of Daphnia to vary through time, it might seem plausible that it could also have altered the phytoplankton species composition, thus impacting the presence or timing of clearing events. However, there were no major changes in phytoplankton taxonomic composition during the three different time periods covered by this study (Effler 1996). Another possibility is that seasonal changes in inorganic turbidity might have occurred as pollutant inputs were altered. However, other than high sediment load during periods of heavy precipitation, phytoplankton biomass has dominated water transparency in Onondaga Lake (Effler 1996). Calcite precipitation, and the turbidity it creates, is common in the lake during periods of high primary production, but necessarily tracks the seasonal changes in algal biomass, changes that we ascribe to Daphnia grazing.

The unusually large impact of Daphnia species, compared with other zooplankton, on algal biomass and production is well established (e.g., Mazumder 1994, Drenner and Hambright 2002). Although few investigators have explored differences among Daphnia species, Tessier et al. (2001) have shown that species identity has implications beyond the simple effect of size. One such species-dependent effect is the difference in seasonal phenology documented here. At the level of the pelagic ecosystem, seasonal changes in trophictransfer efficiency from primary producers to consumers varied depending upon the seasonal phenology of the Daphnia species present. In addition, other ecosystem-level processes within Onondaga Lake appear to have been affected. Lampert et al. (1986) pointed out that soluble reactive phosphorus (SRP) concentrations can increase substantially during the CWP, a phenomenon they attributed to grazing. Similarly, Connors et al. (1996) showed for Onondaga Lake that SRP increased 10- to 40-fold and that the mean phytoplankton $P$ cell quota was elevated during the CWP. In lakes where phosphorus limits algal production, such an increase in phosphorus availability could be important to algal production, or could alter the fundamental nature of nutrient limitation (e.g., Elser et al. 1988). For 19891992, when native Daphnia species dominated, the in- 
crease in SRP occurred in May and June. In 1969, when SRP data are available and the exotic Daphnia dominated during late summer (Onondaga County 1971), SRP concentrations averaged $70 \mu \mathrm{g} / \mathrm{L}$ from April to June when Daphnia were absent and $113 \mu \mathrm{g} / \mathrm{L}$ between July and October when they were present (difference significant, $t=2.44$, df $=15, P<0.02$ ). Again, it is striking that the seasonality of this increase in SRP is substantially shifted by the change in the species composition of the dominant pelagic grazers.

In Onondaga Lake, where environmental forcing is well documented by the history of industrial and municipal pollution, lake-ecosystem properties are strongly linked to species-specific Daphnia responses to changing lake salinity (Effler 1996). The different lifehistories of the native and exotic grazers resulted in changes in the dynamics of the pelagic ecosystem, with implications both for seasonal trophic dynamics and for cascading impacts on nutrient cycling.

\section{Species extinction and replacement vs. local adaptation}

Davis et al. (2005) outline the ways that individual species respond to environmental change (i.e., physiological tolerance to the new environment, local extinction, or rapid local genetic adaptation), and point out that most paleoecological studies in this area to date have focused on local extinction and species range shifts. The results we have reported here are consistent with this perspective. Davis et al. (2005) go on to assert, however, that the role of local adaptation through rapid evolutionary response to a changed environment can also be important. From a paleoecological perspective, zooplankton diapausing eggs provide particularly good opportunities for exploring rapid evolution because they often remain viable in lake sediments for decades or centuries (e.g., Hairston 1996). First, they contain genetic information that has been crucial in determining species identity (Duffy et al. 2000), and past population structure (Weider et al. 1997, Hairston et al. 1999, Kerfoot and Weider 2004). Second, the pace of evolutionary responses to environmental change can be traced by hatching diapausing eggs from different time periods, rearing the animals under controlled laboratory conditions and then reconstructing molecular genetic, physiological, behavioral, or other evolutionary trajectories. The akinetes, cysts, and spores of other aquatic organisms likewise hold out this possibility.

Examples of rapid evolution discovered using studies of zooplankton egg banks are the adaptive changes in D. galeata allozyme frequencies and juvenile growth rates in Lake Constance, central Europe, in response to a change in lake trophic state (Weider et al. 1997, Hairston et al. 2001), and the evolution of Daphnia magna behavioral (Cousyn et al. 2001) and Daphnia retrocurva morphological responses (Kerfoot and Weider 2004) to known or inferred changes in predator abundances. However, rapid responses to selection may not always be possible. The population of $D$. exilis that came to populate the plankton in Onondaga Lake from the 1940s through the 1970s was essentially genetically monomorphic (Hairston et al. 1999). Although ultimately reaching a size of several billion individuals, the population was apparently established by the hatching of a single egg. Constraints on adaptive response also exist if the rate of environmental change is exceedingly rapid (Davis and Shaw 2001). This was apparently the case for the Onondaga Lake daphniids both when the native species disappeared in the early 1900s, and reciprocally when the exotic species went extinct (at least from the water column, if not from the egg bank) after the polluting industry was closed.

Paleoecology of zooplankton (including paleolimnology and the kind of paleogenetics represented by studies of zooplankton egg banks) has been used powerfully to elucidate how populations, communities and ecosystems have responded to environmental change over short time periods (e.g., Kerfoot et al. 1999, Arnott and Yan 2002). However, much has been written in the past few decades about the importance of manipulative, controlled, and replicated experiments for understanding how natural systems function (e.g., Resetarits and Bernardo 1998 and the papers therein). At the same time, others (e.g., Carpenter 1996) have criticized small-scale, rigorously controlled experiments as being excessively artificial. Both approaches have merit (Drenner and Mazumder 1999), yet both are necessarily limited in duration (typically weeks to years) compared with the time scale of much environmental change (decades to centuries). In addition, whole ecosystem experiments are constrained to manipulations that are feasible, ethical and legal. The "natural experiments" that are the focus of paleoecological investigations are unconstrained by such niceties, since humans have intentionally or by accident perpetrated an extraordinary range of environmental manipulations at the ecosystem-to-biosphere scale (e.g., pollution, predator introductions or removals, and global climate change). While the patterns observed cannot be properly interpreted mechanistically in the absence of the insights provided by direct, manipulative experiments, the longterm effects of environmental change can only be appreciated using paleoecological data.

\section{ACKNOWLEDGMENTS}

N. G. Hairston, Jr. is especially grateful to Margaret Davis for teaching a superb course in Quaternary Paleoecology at the University of Michigan; it showed him, as an undergraduate carefully avoiding ecology, how interesting the subject really is. N. G. Hairston also thanks Linda Brubaker (who assisted in that course) and the other organizers of the ESA symposium in honor of Margaret's retirement for the invitation to participate. We thank W. R. Schaffner for counting zooplankton, B. Wagner, N. Ohrazda, J. Meyer, and S. P. Ellner for help with data collection and analysis, L. Brubaker, V. Card, L. De Meester, J. A. Fox, S. Sugita, and an anonymous referee for comments on the manuscript, and C. Driscoll, D. Engstrom, and R. Montione for discussion of the pollution history of Onondaga Lake. Molecular genetic anal- 
yses were carried out at the Evolutionary Genetics Core Facility at Cornell University. This research was supported by the Environmental Protection Agency/National Science Foundation program on Water and Watersheds (EPA grant R82-4771-101), NSF grant DEB-9815365, and U.S. Department of Agriculture (Hatch Project NY(C)-1837407). This is contribution No. 219 of the Upstate Freshwater Institute.

\section{Literature Cited}

Arnott, S. E., and N. D. Yan. 2002. The influence of drought and re-acidification on zooplankton emergence from resting stages. Ecological Applications 12:138-153.

Auer, M. T., M. L. Storey, S. W. Effler, N. A. Auer, and P. Sze. 1990. Zooplankton impacts on chlorophyll and transparency in Onondaga Lake, New York, USA. Hydrobiologia 200/201:603-617.

Bottrell, H. H., A. Duncan, Z. M. Gliwicz, E. Grygeirek, A. Herzig, A. Hillbricht-Ilkowska, H. Kurazawa, P. Larson, and T. Weglenska. 1976. A review of some problems in zooplankton production studies. Norwegian Journal of Zoology 24:419-456.

Bowman, A. W., and A. Azzalini. 1997. Applied smoothing techniques for data analysis: the kernel approach with SPlus illustrations. Oxford University Press, Oxford, UK.

Brooks, J. L., and S. I. Dodson. 1965. Predation, body size, and composition of plankton. Science 150:28-35.

Carpenter, S. R. 1996. Microcosm experiments have limited relevance for community and ecosystem ecology. Ecology 77:677-680.

Cominolli, R. 1990. Smokestacks allegro: the story of Solvay, a remarkable industrial/immigrant village (18801920). Center for Migration Studies, New York, New York, USA.

Connors, S. D., M. T. Auer, and S. W. Effler. 1996. Phosphorus pools, alkaline phosphatase activity, and phosphorus limitation in hypereutrophic Onondaga Lake. Lake and Reservoir Management 12:47-57.

Cottingham, K. L., S. E. Knight, S. R. Carpenter, J. J. Cole, M. L. Pace, and A. E. Wagner. 1997. Response of phytoplankton and bacteria to nutrients and zooplankton: a mesocosm experiment. Journal of Plankton Research 19 : 995-1010.

Cousyn, C., L. De Meester, J. K. Colbourne, L. Brendonck, D. Verschuren, and F. Volckaert. 2001. Rapid, local adaptation of zooplankton behavior to changes in predation pressure in the absence of neutral genetic changes. Proceedings of the National Academy of Sciences (USA) 98: 6256-6260.

Cyr, H., and M. L. Pace. 1993. Magnitude and patterns of herbivory in aquatic and terrestrial ecosystems. Nature 361: $148-150$.

Davis, M. B. 1987. Invasions of forest communities during the Holocene: beech and hemlock in the Great Lakes Region. Pages 373-393 in A. J. Gray, M. J. Crawley, and P. J. Edwards, editors. Colonization, succession and stability. Blackwell Scientific Publications, Oxford, UK.

Davis, M. B., R. R. Calcotte, S. Sugita, and H. Takahara. 1998. Patchy invasion and the origin of a hemlock-hardwoods forest mosaic. Ecology 79:2641-2659.

Davis, M. B., and R. G. Shaw. 2001. Range shifts and adaptive responses to Quaternary climate change. Science 292 : 673-679.

Davis, M. B., R. G. Shaw, and J. R. Etterson. 2005. Evolutionary responses to changing climate. Ecology 86:17041714.

Davis, M. B., S. Sugita, R. R. Calcote, J. B. Ferrari, and L. E. Frelich. 1994. Historical development of alternate communities in a hemlock-hardwood forest in northern Michigan, USA. Pages 19-39 in P. J. Edwards, R. May, and N. R. Webb, editors. Large-scale ecology and conservation biology. Blackwell Scientific Publications, Oxford, UK.
Dawidowicz, P., A. Prijs, A. Engelmayer, A. Martyniak, J. Kozlowski, L. Kufel, and M. Paradowska. 2002. Hypolimnetic anoxia hampers top-down food-web manipulation in a eutrophic lake. Freshwater Biology 47:2401-2409.

DeMott, W. R. 1995. Food selection by calanoid copepods in response to between-lake variation in food abundance. Freshwater Biology 33:171-180.

Drenner, R. W., and K. D. Hambright. 2002. Piscivores, trophic cascades, and lake management. Scientific World 2: 284-307.

Drenner, R. W., and A. Mazumder. 1999. Microcosm experiments have limited relevance for community and ecosystem ecology: comment. Ecology 80:1081-1085.

Duffy, M. A., L. J. Perry, C. M. Kearns, L. J. Weider, and N. G. Hairston, Jr. 2000. Paleogenetic evidence for a past invasion of Onondaga Lake, New York, by exotic Daphnia curvirostris using mtDNA from dormant eggs. Limnology and Oceanography 45:1409-1414.

Effler, S. W. 1996. Limnological and engineering analysis of a polluted urban lake: prelude to environmental management of Onondaga Lake, New York. Springer-Verlag, New York, New York, USA.

Elser, J. J., M. M. Elser, N. A. MacKay, and S. R. Carpenter. 1988. Zooplankton-mediated transitions between $\mathrm{N}-$ and P-limited algal growth. Limnology and Oceanography 33: $1-14$.

Fryer, G. 1996. Diapause, a potent force in the evolution of freshwater crustaceans. Hydrobiologia 320:1-14.

Gomez, A., G. R. Carvalho, and D. H. Lunt. 2000. Phylogeography and regional endemism of a passively dispersing zooplankter: mitochondrial DNA variation in rotifer resting egg banks. Proceedings of the Royal Society of London, Series B 267:2189-2197.

Hairston, N. G., Jr. 1996. Zooplankton egg banks as biotic reservoirs in changing environments. Limnology and Oceanography 41:1087-1092.

Hairston, N. G., Jr., and N. G. Hairston, Sr. 1993. Causeeffect relationships in energy flow, trophic structure, and interspecific interactions. American Naturalist 142:379411.

Hairston, N. G., Jr., C. L. Holtmeier, W. Lampert, L. J. Weider, D. M. Post, J. M. Fischer, C. E. Cáceres, J. A. Fox, and U. Gaedke. 2001. Natural selection for grazer resistance to toxic cyanobacteria: evolution of phenotypic plasticity? Evolution 55:2203-2214.

Hairston, N. G., Jr., L. J. Perry, A. J. Bohonak, M. Q. Fellows, C. M. Kearns, and D. R. Engstrom. 1999. Population biology of a failed invasion: paleolimnology of Daphnia exilis in upstate New York. Limnology and Oceanography 44:477-486.

Hebert, P. D. N. 1995. The Daphnia of North America: an illustrated fauna, Version 1. CD-ROM. University of Guelph, Guelph, Ontario, Canada.

Hebert, P. D. N., and T. L. Finston. 1993. A taxonomic reevaluation of North American Daphnia (Crustacea: Cladocera). I. The D. similis complex. Canadian Journal of Zoology 71:908-925.

Hülsmann, S., and H. Voigt. 2002. Life history of Daphnia galeata in a hypereutrophic reservoir and consequences of non-consumptive mortality for the initiation of the midsummer decline. Freshwater Biology 47:2313-2324.

Kalff, J. 2002. Limnology: inland water ecosystems. Prentice Hall, Upper Saddle River, New Jersey, USA.

Kerfoot, W. C., J. A. Robins, and L. J. Weider. 1999. A new approach to historical reconstruction: combining descriptive and experimental limnology. Limnology and Oceanography 44:1232-1247.

Kerfoot, W. C., and L. J. Weider. 2004. Experimental paleoecology (resurrection ecology): chasing Van Valen's Red

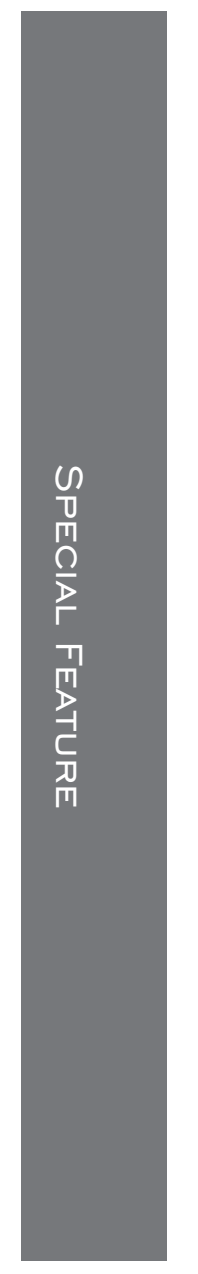


Queen hypothesis. Limnology and Oceanography 49:13001316.

Knoechel, R., and B. Holtby. 1986. Construction and validation of a body-length-based model for the prediction of cladoceran community filtering rates. Limnology and Oceanography 31:1-16.

Lampert, W. 1987. Feeding and nutrition in Daphnia. Memorie dell'Istituto Italiano di Idrobiologia 45:143-192.

Lampert, W., W. Fleckner, H. Rai, and B. E. Taylor. 1986. Phytoplankton control by grazing zooplankton: a study on the spring clear-water phase. Limnology and Oceanography 31:478-490.

Lampert, W., and U. Sommer. 1997. Limnoecology: the ecology of lakes and streams. Oxford University Press, Oxford, UK.

Lehman, J. T. 1984. Grazing, nutrient release, and their impacts on the structure of phytoplankton communities. Pages 75-96 in D. G. Meyers and J. R. Strickler, editors. Trophic interactions within aquatic ecosystems. Westview Press, Boulder, Colorado, USA.

Lovette, G. M., and H. Rueth. 1999. Soil nitrogen transformations in beech and maple stands along a nitrogen deposition gradient. Ecological Applications 9:1330-1344.

Matthews, D. A., S. W. Effler, C. M. Brooks, C. A. Siegfried, and M. E. Spada. 2001. Responses of Onondaga Lake, New York, to early stages of rehabilitation: unanticipated ecosystem feedbacks. Water Environment Research 73:691703.

Mazumder, A. 1994. Phosphorus-chlorophyll relationships under contrasting zooplankton community structure: potential mechanisms. Canadian Journal of Fisheries and Aquatic Science 51:401-407.

McNaughton, S. J., G. Zuniga, M. M. McNaughton, and F. F. Banyikwa. 1997. Ecosystem catalysis: soil urease activity and grazing in the Serengeti ecosystem. Oikos 80:467469.

Meyer, M. A., and S. W. Effler. 1980. Changes in the zooplankton of Onondaga Lake 1969-1978. Environmental Pollution (Series A) 23:131-152.

Michels, E., E. Audenaert, R. Ortells, and L. De Meester. 2003. Population genetic structure of three pond-inhabiting Daphnia species on a regional scale (Flanders, Belgium). Freshwater Biology 48:1825-1839.

O'Brien and Gere Engineers. 1990. History of the Willis Avenue Plant petroleum storage facility and associated "hot-spots." Internal report prepared for Allied-Signal, Inc., Solvay, New York, USA.

Onondaga County. 1971. Onondaga Lake study. Project No. 11060, FAE 4/71. Water Quality Office, U.S. Environmental Protection Agency, Washington, D.C., USA.
Ortega-Mayagoitia, E., X. Armengol, and C. Rojo. 2000. Structure and dynamics of zooplankton in a semi-arid wetland, the National Park Las Tablas de Daimiel (Spain). Wetlands 20:629-638.

Post, D. M., J. P. Taylor, J. F. Kitchell, M. H. Olson, D. E. Schindler, and B. R. Herwig. 1998. The role of migratory waterfowl as nutrient vectors in a managed wetland. Conservation Biology 12:910-920.

Price, P. W. 1997. Insect ecology. Third edition. John Wiley and Sons, New York, New York, USA.

PTI Environmental Services. 1992. Onondaga Lake RI/FS Site History Report. Internal Report, PTI Contract C31302. PTI Environmental Services, Bellevue, Washington, USA.

R Development Core Team. 2004. R: a language and environment for statistical computing. R Foundation for Statistical Computing, Vienna, Austria.

Remane, A. 1971. Ecology of brackish water. Pages 1-210 in A. Remane and C. Schlieper, editors. Biology of brackish water. Second edition. Die Binnengewässer. Volume 15. E. Schweiserbart, Stuttgart, Germany.

Resetarits, W. J.,Jr., and J. Bernardo. 1998. Experimental ecology: issues and perspectives. Oxford University Press, Oxford, UK.

Root, R. B. 1967. The niche exploitation pattern of the Bluegray Gnatcatcher. Ecological Monographs 37:317-350.

Rowell, H. C. 1996. Paleolimnology of Onondaga Lake: the history of anthropogenic impacts on water quality. Lake and Reservoir Management 12:35-45.

Schaffner, W. R., N. G. Hairston, Jr., and R. W. Howarth. 1994. Feeding rates and filament clipping by crustacean zooplankton consuming cyanobacteria. Internationale Vereinigung für Theoreticshe und Angewandte Limnologie, Verhandlungen. 25:2375-2381.

Sterner, R. W., and J. J. Elser. 2002. Ecological stoichiometry: the biology of elements from molecules to the biosphere. Princeton University Press, Princeton, New Jersey, USA.

Sze, P., and J. M. Kingsbury. 1972. Distribution of phytoplankton in a polluted saline lake, Onondaga Lake, New York. Journal of Phycology 8:25-37.

Tessier, A. J., E. V. Bizina, and C. K. Geedey. 2001. Grazerresource interactions in the plankton: are all daphniids alike? Limnology and Oceanography 46:1585-1595.

Weider, L. J., W. Lampert, M. Wessels, J. K. Colbourne, and P. Limburg. 1997. Long-term genetic shifts in a microcrustacean egg bank associated with anthropogenic changes in the Lake Constance ecosystem. Proceedings of the Royal Society of London, Series B 264:1613-1618. 